\title{
Lysozyme interaction with liposomes: thermodynamics of binding
}

\author{
G. P. Gorbenko \\ Kharkiv State Liniversity \\ PI. Svobody, 4, Kharkiv, 61077, Ukraine
}

\begin{abstract}
Using the method of competitive analysis the interaction of lysozyme with liposomes composed of phosphatidylcholine and diphosphatidylglycerol has been studied. In terms of the lattice and continuum models of large ligand adsorption to membrane thermodynamic parameters for the protein-lipid complexes have been estimated. Lysozyme binding to liposomes containing more than $25 \mathrm{~mol} \%$ of DPG has been found to be characterized by the positive cooperativity, originating, presumably, from the self-association of the bound protein.
\end{abstract}

Introduction. Protcin-lipid interactions are known to play an important rolc in determining the structural and functional properties of biomembranes [1]. Protein binding to lipid bilayer is characterized by a number of peculiarities, being essential for thermodynamic analysis of the equilibria in protein-lipid systems. These peculiarities originate, in particular, from i) large size of the protein, capable of forming several simultaneous contacts with the membrane surface; ii) steric area-excluding interactions between adsorbed protein molecules; iii) strong dependence of the binding on the ligand shape, i. e. on the geometrical arrangement of binding contacts in the protein-lipid complex. To date, two classes of models for protein adsorption on surface have been proposed, namely lattice and continuum ones [2-7]. In terms of the lattice models lipid bilayer is represented by a regular array of binding contacts (subunits), forming protein binding sites according to the size and shape of contact region [2-4]. Continuum models treat the protein adsorption to surface on the basis of the theories of two-dimensional hard-particle fluids [7]. Although these two classes of models seem to be most adequate for thermodynamic analysis of protein-lipid interactions, a major part of the data reported in the literature have bcen analyzed within the framework of traditional Langmuir approach. However, because of peculiar features of the protein-lipid systems this

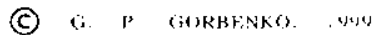

approach does not allow to obtain correct quantitative characteristics of the protein association with lipid bilayer [4].

In the present study some lattice and continuum models of large ligand adsorption on surface have been employed to estimate binding parameters for the complexes of cationic protein lysozyme with liposomes, composed of neutral (phosphatidylcholine $(\mathrm{PC})$ ) and negatively charged (diphosphatidylglycerol (DPG)) lipid species. Lysozyme is not a membrane protein, but it currently widely used in the model studies due to its ability to associate with lipids by means of electrostatic and hydrophobic interactions [8-10].

Materials and Methods. Egg yolk PC and beef heart DPG were purchased from Bakpreparat (Kharkiv, Ukraine). Both phospholipids gave single spots by thin layer chromatography in the solvent system chloroform:methanol:acetic acid:water, 25:15:4:2, $\mathrm{v} / \mathrm{v})$. Egg white lysozyme was obtained from «Reanal» (Hungary). Unilamellar phospholipid vesicles were prepared by the method of ethanol injection. $1 \mathrm{ml}$ of the ethanol lipid solution containing appropriate amounts of $P C$ and DPG was injected into $13 \mathrm{ml}$ of $10 \mathrm{mM}$ Tris- $\mathrm{HCl}$ buffer, $\mathrm{pH} 7.4$, under continuous stirring. Ethanol was then removed by dialysis. Phospholipid concentration was determined according to the procedure of Bartlett [11]. Lysozyme binding to liposomes was monitored using the method of competitive analysis, described in detail previously [12$14]$. 
Results and Discussion. In order to follow lysozyme interaction with liposomes a competition between the protein and fluorescent probe 4-(dimethylaminostyryl)-1-methylpiridine $n$-toluenesulfonate (DSM) for the binding sites on the bilayer surface has becn examined. Such a competition manifests itself in the decrease of fluorescence intensity of membranebound DSM upon addition of the protein $[11,12]$. Typical curves illustrating the probe displacement by lysozyme are presented in Fig. 1. Previous studies have shown that in liposomal membranes there exist two types of DSM binding centers [15]. Assuming that the centers of only one type are responsible for the competition effects, an approach to the estimation of the protein binding parameters has been developed $\{13,14\}$. In the present work this approach has been extended to the case of competition for both types of DSM binding centers. The first step of the data analysis consists in the estimation of the fraction of surface area, occupied by the protein ( $\Phi)$ from experimental dependencies of DSM fluorescence intensity $\left(I_{p}\right)$ on the protein concentration $(P)$. Fluorescence intensity of DSM bound to the sites of two types can be represented by:

$$
I_{p}=B_{1} f_{1}+B_{2} f_{2}
$$

where $B_{1}, B_{2}$ are the concentrations of the probe, $f_{1}$, $f_{2}$ are fluorescence intensities of one mole of the probe bound to the centers of the first and second type, respectively '(note that fluorescence of DSM in solution is negligibly small compared to that in lipid bilayer). The concentration of free probe $\left(Z_{f}\right)$ is given by:

$$
\begin{gathered}
Z_{f}=Z_{0}-B_{1}-B_{2}=Z_{0}-\frac{l_{1}}{f_{2}}- \\
-B_{1}\left(1-\frac{f_{1}}{f_{2}}\right)=a_{1}-B_{1} a_{2},
\end{gathered}
$$

where $Z_{0}$ is the total probe concentration. Binding constants are defined by the expressions:

$$
K_{1}=\frac{B_{1}}{Z_{f} N_{1}^{f}} ; K_{2}=\frac{B_{2}}{Z_{f} N_{2}^{f}},
$$

where $N_{1}^{f}, N_{2}^{f}$ are the concentrations of free binding sites. From eq. (3) one obtains:

$$
N_{1}^{f}=\frac{B_{1}}{Z_{f} K_{1}} ; N_{2}^{f}=\frac{B_{2}}{Z_{f} K_{2}} ; \frac{B_{1}}{K_{1} N_{1}^{f}}=\frac{B_{2}}{K_{2} N_{2}^{f}} .
$$

Denoting total number of the sites by $N_{1}$ and $N_{2}$, the fraction of surface area, occupied by the protein, can be written as:

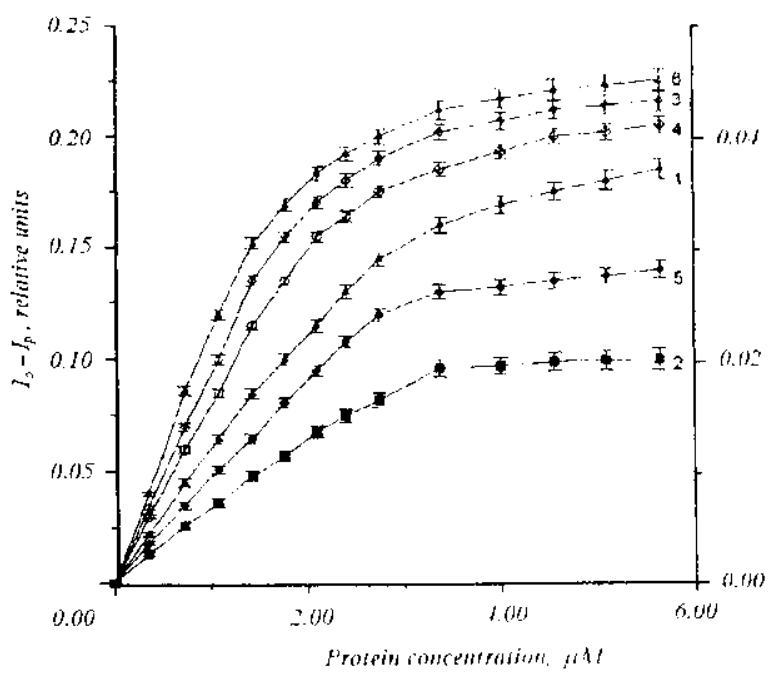

Fig. 1. The change of DSM fluorescente intensity in the presence of lysozyme. DPG content, mol\%: $1-5 ; 2-11: j-25 ; 4-43$; $5-67 ; 6-100$. Lipid concentration, $\mu \mathrm{M}: 1-67 ; 2-92 ; j \ldots$ $12 ; 4-5 ; 5-1 ; 0-2$. The probe concentration is $5 \mu \mathrm{M}$. The left $\mathrm{Y}$-axis corresponds to the curves 2 and $6 . l_{0}$ is DSM fluorescence intensity in the absence of lysozyme, $I_{p}$ is DSM fluorescence intensity upon the protein addition

$$
\Phi=1-\frac{N_{1}^{f}+B_{1}}{N_{1}}=1-\frac{N_{2}^{f}+B_{2}}{N_{2}} \text {. }
$$

From the eq. (1), (2), (4) $u(5)$ it follows that:

$$
B_{2}=\frac{B_{1} N_{2}\left(1+\frac{1}{K_{1}\left(a_{1}-B_{1} a_{2}\right)}\right)}{N_{1}\left(1+\frac{1}{\left(K_{2}\left(a_{1}-B_{1} a_{2}\right)\right.}\right)}=\frac{I_{1}-B_{1} f_{1}}{f_{2}} .
$$

Relationship (6) can be transforned to:

$$
a B_{1}^{2}+b B_{1}+c=0
$$

where

$$
\begin{gathered}
a=K_{1} K_{2}\left(1-\frac{f_{1}}{f_{2}}\right)\left(N_{2}+\frac{f_{1}}{f_{2}} N_{1}\right) \\
b=-N_{1} K_{1}\left(\frac{I_{p} K_{2}}{f_{2}}\left(1-\frac{f_{1}}{f_{2}}\right)+\frac{f_{1}}{f_{2}}+\frac{f_{1} K_{2}}{f_{2}}\left(Z_{0}-\frac{I_{p}}{f_{2}}\right)\right)- \\
-N_{2} K_{2}\left(1+K_{1}\left(Z_{4}-\frac{I_{p}}{f_{2}}\right)\right)
\end{gathered}
$$




$$
\begin{gathered}
c=\frac{I_{F} N_{1} K_{1}}{f_{2}}\left(1+Z_{0} K_{0}-\frac{I_{F} K_{2}}{f_{2}}\right) \\
B_{1}=\frac{-b-\sqrt{D}}{2 a} ; D=b^{2}-4 a c .
\end{gathered}
$$

Using the value of $B_{l}$, obtained in such a way, from the eq. (1), (4) and (5) one can find $\Phi$ value, corresponding to a given fluorescence intensity $I_{0}$. Parameters $N_{1}, N_{2}, K_{1}, K_{2}, f_{1}, f_{2}$ for liposomes under study have been determined previously [13]. From experimental curves $I_{f}(P)$ measured at $5-8$ concentrations of each type of liposomes the dependencies $\Phi(P)$ have been obtained. Second step of the data treatment was aimed at the determination of the binding parameters characterizing the complexes of lysozyme with lipids-association constant $\left(K_{u}\right)$ and a number of lipid molecules per molecule of the bound protein $(n)$. In analyzing experimental results two limiting cases, corresponding to the linear and discoid ligand shape, have been considered. Within the framework of the lattice models the protein binding to liposomal membranes, modeled as hexagonal lattice of lipid molecules, has been described by the following relationships $[2,3]$ :

For linear ligand

$$
\begin{gathered}
K_{u} F=\frac{r}{1-n r}\left(\frac{1-(1-\lambda) n r}{1-n r}\right)^{n-1}, \\
r=\frac{B}{L} ; \lambda=\frac{z^{*}-2}{z^{*}}-\frac{2}{n z^{*}}
\end{gathered}
$$

For disc-like ligand

$$
K_{u} F=\frac{r}{1-n r} \exp \left(\frac{a n r}{1-u r r}\right),
$$

where $B, F$ are the concentrations of bound and free protein, respectively, $L$ is the total lipid concentration, $z^{*}$ is the lattice coordination number $\left(z^{*}=6\right), \alpha$ is the parameter of excluded area $(o=3), \omega=2 \sqrt{ } 3 \mathrm{v} / \pi$. Assuming that protein-binding contacts are not closepacked (e. g. when the protein interacts only with one kind of the lipid species) the model of disc binding to dilute centers has been used [4]:

$$
K_{u} F=\frac{r}{(1-n r)^{2}} \exp \left(\frac{a n r}{1-n r}\right) .
$$

For the sake of comparison the data have been also treated in terms of continuum model, represented by the equations $[7]$ :

$$
\begin{aligned}
K_{a} F= & \Phi G(\Phi) ; \ln G=-\ln (1-\Phi)-\varepsilon- \\
& -1+\frac{1}{1-\Phi}+\frac{\varepsilon}{(1-\Phi)^{2}}
\end{aligned}
$$

where $\varepsilon$ is a shape-dependent parameter $(\varepsilon=1$ for disc-like ligand and $\varepsilon=(g / \pi)(1+1 / g)^{2}$ for rectangle with axial ratio $g$ ). The values of $K_{0}$ and $n$, providing the best fit of the data set have been found by minimizing a function:

$$
f=\frac{1}{m} \sum\left(P_{0}^{\prime}-P_{0}^{c}\right)^{2}
$$

where $P_{0} e$ is the protein concentration, determined experimentally, $m$ is the number of experimental points, $P_{0}{ }^{c}$ is the protein concentration calculated for a given set of the parameters $n$ and $K_{a}, P_{0}{ }^{c}=B+F$; $B=\Phi L / n$ the value of $F$ was derived from cqs. (9) $-(12)$.

As can be seen in Table, for both types of the models used the value of $n$ dramatically decreased with the increasing DPG content in the lipid bilayer, and in some cases $n$ tended to zero upon fitting. Such a behaviour of this parameter may, in principle, be a consequence of an increase of the packing density of protein molecules at the bilayer surface. However, taking into account the cross-section of lysozyme (ca. $2700 \mathrm{~A}^{2}$ ) [16], corresponding to an area of ca. $39 \mathrm{PC}$ molecules $\left(S_{\mathrm{PC}} 70 \mathrm{~A}^{2}\right)$ or ca. 23 molecules of $\mathrm{DPG}$ $\left(S_{\mathrm{DPG}} \approx 120 \mathrm{~A}^{2}\right)[17]$ the values of $n \leq 1$ seem to be unreasonable. Assumption that lysozyme binds to dilute centers (this may be the case when the protein forms only electrostatic contacts with DPG headgroups) does not improve the situation. Drastic decrease of $n$ reflects the steepening of the binding curves, that can stem, in particular, from the cooperativity of binding process. Cooperative effects have been considered in terms of the lattice model of linear ligand adsorption to membrane, described by relationships [4]:

$$
\begin{gathered}
K_{\alpha} F=B_{0}(1+A / p)^{\delta}(1+A p)^{\gamma-\delta} ; \\
B_{0}=\frac{r}{1-n r}\left(\frac{1-(1-\lambda) n r}{1-n r}\right)^{\gamma} ; p=\frac{\lambda n r}{1-n r} ; \\
A=\left(a^{*}-1\right) /\left(a^{*}+1\right) ; \\
a^{*}=\left[1+\frac{4(\eta-1) \lambda n r(1-n r)}{1-(1-\lambda) n r)^{2}}\right]^{1 / 2},
\end{gathered}
$$

where $\eta$ is the cooperativity parameter. Application of this model yields rather reasonable estimates of $n$ (Table) and allows to assume that upon DPG content exceeding $25 \mathrm{~mol} \%$ lysozyme binding to liposomes is characterized by a positive cooperativity $(\eta \approx 1.2-$ 1.3). In this context it seems of importance to note that cooperative phenomena are widespread in biological systems and play significant role in the interaction of the proteins with small ligands and 
GORBENKO (i.

Parameters of lysozyme binding to liposomes

\begin{tabular}{|c|c|c|c|c|c|}
\hline \multirow{4}{*}{ Parametets } & \multicolumn{5}{|c|}{ Liposome } \\
\hline & Pri $1 \mathrm{~PB} 18 \cdot 1$ & $P C^{\prime}: D P C_{r}:: 1$ & $P G: D P G ; 3: 1$ & $\mathrm{PG} \cdot \mathrm{DPG}+4: 3$ & $P G_{i}: I D P G ; \quad 1:$ \\
\hline & \multicolumn{5}{|c|}{ DPG content, mol\% } \\
\hline & 5 & 11 & 25 & 43 & 67 \\
\hline & \multicolumn{5}{|c|}{$\begin{array}{l}\text { Lattice model } \\
\text { Linear ligand }\end{array}$} \\
\hline$K_{u}, \mathrm{M}^{-1}$ & $(1.6 \pm 0.3) \cdot 10^{5}$ & $(1.1 \pm 0.2) \cdot 10^{7}$ & $(1.5 \pm 0.3) \cdot 10^{4}$ & $(3.5 \pm 0.8) \cdot 10^{4}$ & $(1.9 \pm 0.4) \cdot 1$ \\
\hline \multirow[t]{2}{*}{$n$} & $20 \pm 5$ & $21 \pm 5$ & $4 \pm 1$ & $1 \pm 0.2$ & $6 \pm 2$ \\
\hline & \multicolumn{5}{|c|}{ Disk-like ligand } \\
\hline$K_{u}, \mathrm{M}^{-1}$ & - & - & $(9.8 \pm 1.0) \cdot 10^{4}$ & $(7.2 \pm 1.5) \cdot 10^{4}$ & $(2.4 \pm 0.4) \cdot 10$ \\
\hline \multirow[t]{2}{*}{$n$} & - & - & $\rightarrow 0$ & $\rightarrow 0$ & $\rightarrow 0$ \\
\hline & \multicolumn{5}{|c|}{ Dilute centers, Disk-like ligand } \\
\hline$K_{u}, \mathrm{M}^{-1}$ & $(5.2 \pm 1.1) \cdot 10^{5}$ & $(2.7 \pm 0.7) \cdot 10^{8}$ & $(8.9 \pm 1.9) \cdot 10^{4}$ & $(7.1 \pm 1.4) \cdot 10^{4}$ & $(1.2 \pm 0.3) \cdot 10$ \\
\hline \multirow[t]{2}{*}{$n$} & $14 \pm 3$ & $18 \pm 4$ & $1.1 \pm 0.2$ & $\rightarrow 0$ & $1 \pm 0.2$ \\
\hline & \multicolumn{5}{|c|}{ Cooperativity, Linear ligand } \\
\hline$K_{u}, \mathrm{M}^{-1}$ & $(1.4 \pm 0.3) \cdot 10^{5}$ & $(1.2 \pm 0.3) \cdot 10^{7}$ & $(2.5 \pm 0.6) \cdot 10^{6}$ & $(7.2 \pm 1.6) \cdot 10^{6}$ & $(2.5 \pm 0.7) \cdot 10$ \\
\hline$n$ & $19 \pm 4$ & $1 \pm 0.2$ & $17 \pm 3$ & $17 \pm 4$ & $16 \pm 3$ \\
\hline \multirow[t]{2}{*}{$\eta$} & 1.000 .02 & $1.03 \pm 0.03$ & $1.2 \pm 0.05$ & $1.3 \pm 0.05$ & $1.2 \pm 0.06$ \\
\hline & \multicolumn{5}{|c|}{$\begin{array}{l}\text { Continuum model } \\
\text { Linear ligand }(g=10)\end{array}$} \\
\hline$K_{u}, \mathrm{M}^{-1}$ & $(1.8 \pm 0.4) \cdot 10^{6}$ & $(1.8 \pm 0.5) \cdot 10^{8}$ & $(5.2 \pm 1.1) \cdot 10^{5}$ & $(7.5 \pm 1.6) \cdot 10^{5}$ & $(5.5 \pm 1.2) \cdot 1$ \\
\hline \multirow[t]{2}{*}{$n$} & $20.5 \pm 5$ & $19 \pm 4$ & $0.6 \pm 0.2$ & $0.2 \pm 0.06$ & $0.2 \pm 0.06$ \\
\hline & \multicolumn{5}{|c|}{ Disk-like ligand } \\
\hline$K_{u} \cdot \mathrm{M}^{-1}$ & - & - & $(1.0 \pm 0.3) \cdot 10^{5}$ & $(1.8 \pm 0.5) \cdot 10^{5}$ & $(2.3 \pm 0.6) \cdot 1$ \\
\hline \multirow[t]{2}{*}{$n$} & - & - & $1.0 \pm 0.2$ & $0.3 \pm 0.08$ & $0.5 \pm 0.1$ \\
\hline & \multicolumn{5}{|c|}{ Disk-like ligand, Self-association, $K_{1:}=I$} \\
\hline$K_{u}, \mathrm{M}^{-1}$ & - & $\ldots$ & $(4.8 \pm 1.1) \cdot 10^{4}$ & $(4.4 \pm 0.9) \cdot 10^{4}$ & $(4.9 \pm 1.0) \cdot 1$ \\
\hline$n$ & - & - & 33 & 30 & 26 \\
\hline$\eta$ & - & - & 2 & 2 & 2 \\
\hline
\end{tabular}

*Unsuccessful fitting. 
macromolecules $[18,19]$. One of the most probable reason for this effect is the self-association of bound protein. The fact that cooperativity is not observed at the low mole percent of DPG could be interpreted as follows. Increase of the surface charge density of the lipid bilayer can result in i) enhancing the screening of the net protein charge and ii) increasing the amount of the bound protein molecules per unit of the membranc area. At a certain DPG content (in our case ca. $25 \mathrm{~mol} \%$ ) the superposition of these effects may lead to appearance of the conditions favourable for the formation of the protein associates. In this respect it seemed of interest to analyze the data in terms of the continuum model for the adsorption of a large self-associating ligand to a surface 171 . The main relationships of this model can be written as:

$$
\begin{gathered}
K_{u} F=\Phi_{1} G_{1}\left(\Phi_{1}, \Phi_{z}\right) ; \\
\Phi_{z}=z K_{1 z} \frac{G_{1}\left(\Phi_{1}, \Phi_{z}\right)^{z}}{G_{z}\left(\Phi_{1}, \Phi_{z}\right)} \Phi_{1}^{z} ; \\
\ln G_{1}=-\ln (1-\Phi)+\frac{3 \Phi_{1}+\left[\frac{2}{q}+\frac{1}{q^{2}}\right] \Phi_{z}}{1-\Phi}+ \\
\left.\ln G_{2}=-\ln (1-\Phi)+\frac{3 \Phi_{z}+\left(2 q+q^{2}\right) \Phi_{1}}{\left(1-\frac{1}{q} \Phi_{2}\right.}\right)^{2} \\
+\frac{\left(\Phi_{1}+q \Phi_{1}\right)^{2}}{(1-\Phi)^{2}}
\end{gathered}
$$

where $\Phi=\Phi_{1}+\Phi_{2}$ and $q=R_{z} y R_{l}, R_{z}$ and $R_{1}$ are the radii of the circles representing $z$-mer and monomer, respectively, $K_{i=}$ is the constant characterizing the formation of $z$-mer. In the case when area is conserved on self-association $q=z^{1 / 2}$. The complexity of this model does not allow to ascertain the set of the parameters $\left(K_{u}, n, K_{l}, z\right)$ unequivocally, but we have made an attempt to obtain some semi-quantitative estimates. The data treatment procedure was based on the calculation of $\Phi_{z}\left(\Phi_{1}=\Phi-\Phi_{z}\right)$ by numerical solution of the eq. (15) with the subsequent evaluation of $F$ (cq. (14)), $B$ and $f$ (eq. (13)). The value of $n$ was put equal to $S_{\mathrm{p}} / S_{u}$, where $S_{i 2}$ is the mean area per lipid headgroup $\left(S_{a}=\left(S_{\mathrm{Po}} f^{*}+S_{\mathrm{pPG}}\right) /\left(f^{*}+1\right), f^{*}\right.$ is the molar ratio $\mathrm{PC}$ to $\mathrm{DPG}$ ), while $K_{l_{2}}$ was varied in the range $0.01-40$ (the upper limit was determined by the requirement $\Phi_{1}>0$ ). Under such conditions some sets of the parameters $\left(K_{u}, K_{i z}, z\right)$ corresponding to at minimum of the function $f$ have been derived for the cases when $\eta$ differs from 1 . As can be seen from Table 1 , such sets, obtained, in particular, for $K_{12}=$
$=1$, provide arguments in favour of the assumption that preferential form of the protein associates is dimer, only for DPG liposomes evidence for tetramer formation has been obtained. The existence of the minimum of the function $f$ is illustrated in Fig. 2 (minimum is observed at $z=2$ ) and Fig. 3 (minimum is observed at $z=4$ ).

Conclusions. The results of the present study can be summarized as follows. Among lattice models of

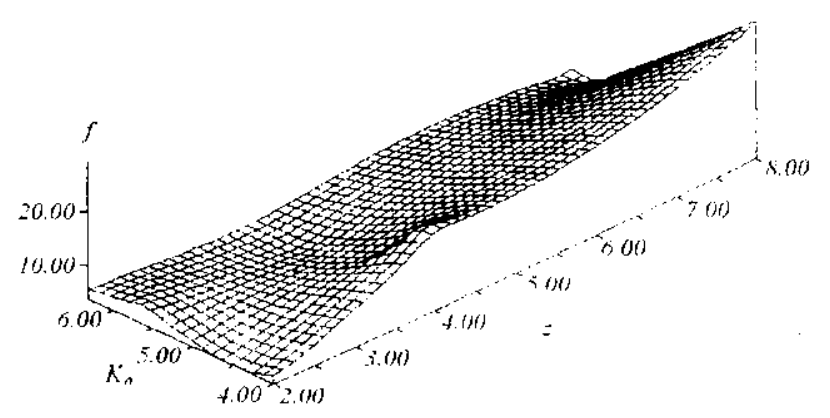

Fig. 2. Three-dimensional diagram, illustrating the denendency of function $f$ on $K_{c}$ and $z$ for liposomes, containing $43 \mathrm{~mol} / 1 / 1 \mathrm{DPG}$. The $f$ values (z-axis) are given as $f \cdot 10^{13}, K_{u}$ values (teft botmon axis) are: given as $K_{i,} \cdot 10^{-4} ; K_{i z}=1$

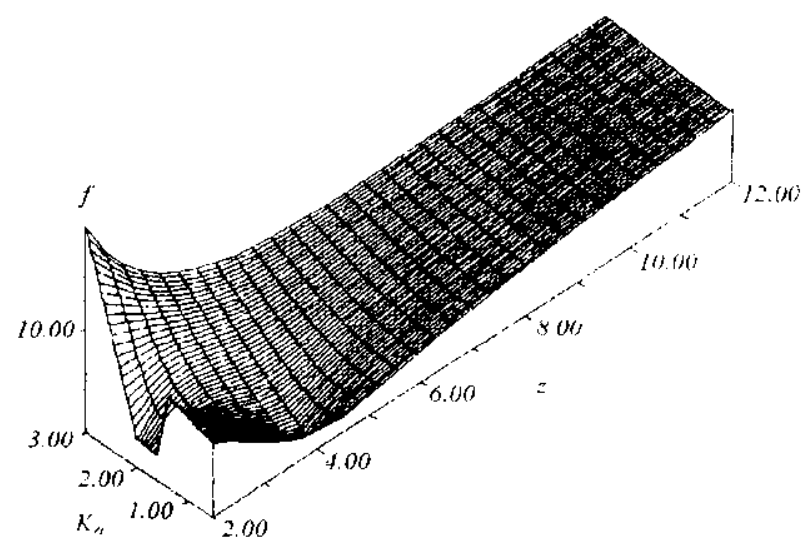

Fig. 3. Three-dimensional diagram, illustrating the dependency of function $f$ (eq. (13)) on $K_{a}$ and $z$ for liposomes, composed of IPPG; The $f$ values (z-axis) are given as $f \cdot 10^{13}, K_{u}$ values (left buitom axis) are given as $K_{t,} \cdot 10^{-6} ; K_{t z}=1$ 
large ligand adsorption to membranes the model of cooperative binding of linear ligand proved to be most adequate for thermodynamic description of lysozyme interaction with liposomes. Lysozyme binding to liposomal membranes containing more than $25 \mathrm{~mol} \%$ of DPG is characterized by a positive cooperativity, arising presumably from the self-association of bound protein.

Acknowledgments. I am very grateful to referee for the helpful suggestions aimed at the article improvement.

\section{Г. П. Горбенко}

Вздемодія лізоциму 3 ліюбсомами: термодинаміка зв'язування

\section{Резюме}

Методом конкурентного аналізу досліджували взасмодію лізоииму з піпосомами, сформованими з фосфатидилхоліну та діфосфатидилеліцерину: $\vee$ рамках решіткових та континуальних ноделеи адсорбйї "ениких лісандів на поверхні зроблено оцінку термодинаміниту параметрів утворення білок-ліпідних комплексів. Встановльно, ицо взаємодія білка з ліпосомами, у яких 'астка дифосфаты излліцерину склауас понад 25 мол\% характеризустися позитивноко кооперапивністю, яка може бути зумовлена самоасонімією молекул зб яззаного білка.

\section{Г. П. Горбенко}

Взаимодействие лизоцимі с липосомами: термодинамика связывания

\section{Резюме}

методом конкурентного анаяиза исследовано взаимодействие тизоиияа с жипосома.ин, состояицми из смесей фосфатидилхолина с дифосфатидинтицерином. В рамках решеточных и континуальных моделеи адсорбиии больщих лисандов на поверхности оценены терлодинамические параметры образования белок-липидных комилексов. Установлено, что при содержании дифосфатидилеличерина, превьианюцем 25 мол\% взаимодействие тизоцима с иипидным бислоен характеризуепся положительной кооператияностью, обусловленной, по-видимому, самоассощиацией мемккул связанного белкка.

\section{REFERENCES}

1. Sankaram M., Mursh D. Protein-lipid interactions with peripheral membrane proteins // Protein-Lipid Interactions / Ed. A. Watts.-Amsterdam: Elsevier, 1993.-P. 127-162.

2. Stankowski S. Large ligand adsorption to membranes. I. Linear ligands as a limiting case // Biochim. et biophys. acta.1983.-735. N 3.-t'. 341-351.

3. Stankowski S. Large ligand adsorption to membranes. II. Disc-like ligands and shape dependence at low saturation // Biochim. et biophys acta. $-1983 .-735$, N 3.-P. 352-360.
4. Stankowski S. Large ligand adsorption to membranes. III. Cooperativity and general ligand shapes $/ /$ Biochim. et biophys. acta $-1984 .-777$, N 2.- P. $167-182$.

5. Tamm L., Bartoldus I. Antibody binding to lipid model membranes. The large ligand effect // Biochemistry.-1988.27.-P. $7453-7458$.

6. Heimburg $T$, Marsh D. Protein surface distribution and protein-protein interations in the binding of peripheral proteins to charged lipid nembranes // Biophys. J. - 1995.68. -P. 536-546.

7. Chatelier R. C., Minton A. P. Adsorption of globular proteins on locally planar surfaces: models for the effect of excluded surface area and aggregation of adsorbed protein on adsorption equilibria // Biophys. J. -1996. -71 -P. 2367-2374.

8. Образиов В. В., Тенчов Б. Г., Данилов В. С. Влияние белоклипидного взаимодействия на структуру искусственной везикулярной мембраны // Докл. АН СССР.-1976.227, № 3.-C. 735-738.

9. Образцов В. В., Селищева А. А., Козлов Ю. П. О влиянии конформации молекулы белка на характер его взаимодейсгвия $c$ фосфолипидным бислоем // Биофизика.1983.-28, № 3.-C. 412-417.

10. Posse E, De Arcuri B., Morero R. Lysozyme interactions with phospholipid vesicles: relationships with fusion and release of aqueous content // Biochim. et biophys. acta.-1994.-1193, N 2.-P. 101-106.

11. Кейтс М. Техника липидологии.-М.: Мир, 1975.-322 с.

12. Горбенко Г. ПТ. Применение метода конкурентного анализа для исследования белоклипидыых взаимодействий // Укр. биохим. журн.-1994.-66, № 3.- С. 99-104.

13. Горбенко $\Gamma$. П. Конкурентное взаимодействие флюоресцентного зонда 4-(n-диметиламиностирил)-1-метилпиридиний n-толуолсульфоната и лизоцима с липосомами // Биофизика.-1996.-41, № 2.-C. 355-362.

14. Горбенко Г. IT. Исследование взаимодействия рибонуклеазы с липосомами методом конкурентного анализа // Укр. биохим. журн.-1996.-68, № 1.-C. 55-60.

15. Горбенко $Г$. П., Дюб́ко Т. С. Взаимодсйствие 4-(п-диметиламиностирил)-1-метилпиридиний n-толуолсульфоната с липосомами: анализ спектров флюоресценции // Биофизика.-1996.-41, № 2.-С. 348-354.

16. Качалова Г. С., Ланина Н. Ф., Морозов В. Н., Морозова T. Я., Шияпникова Е. А., Атанасов Б. П. Рентгенофлюоресцентное исследование ионног состава кристаллов лизоцима // Биофизика.-1995.-40, № 2.-С. 274-282.

17. Ивков В. Г., Берестовский $Г$. Н. Динамическая структура липидного бислоя.-М.: Наука, 1981.-296 с.

18. Perutz $M$. Mechanisms of cooperativity and allosteric regulation on proteins.-Cambrige: Univ press, $1990 .-101 \mathrm{p}$

19. Di Cera $E$. Thermodynamic theory of site-specific binding processes in biological macromolecules.-Cambrige: Univ. press, $1995 .-296$ p. 